\title{
OXISOL RESISTENCE TO PENETRATION IN NO-TILL SYSTEM AFTER SOWING
}

\section{VINICIUS DE V. ROS ${ }^{1}$, CRISTIANO M. A. DE SOUZA ${ }^{2}$, ANTONIO C. T. VITORINO ${ }^{3}$, LEIDY Z. L. RAFULL ${ }^{4}$}

\begin{abstract}
If inappropriately conducted, management and sowing practices may compromise the environment and the profitability of the agricultural activity. The aim of this study was to analyze the furrow opener mechanisms action and the level of load applied to soil firming mechanism in no-till, on the Oxisol resistance to penetration during soybean sowing, under three soil moistures. The experiment was arranged in split-split plot design, in which the plots were composed by three soil moistures $(23.8 ; 25.5$ and $27.5 \%$ b.s.), two furrow opener mechanisms subplots (double disks and furrow plough) and the split-split plot of three levels of load applied to soil firming mechanism $(12.2 ; 18.5$ and $24.1 \mathrm{kPa})$, according to randomized blocks design, with three replications. The soil moisture provided different resistance behavior to penetration with the depth, on the seedbed, independently of the furrow opener and the level of load applied to soil firming mechanism. The furrow plough use provided less soil resistance to penetration when compared to the double disk furrow opener, on the seedbed, independently of the soil moisture and the level of load applied to soil firming mechanism. The pressure applied by soil firming mechanism of $18.5 \mathrm{kPa}$ provided the lower resistance to penetration, when the furrow plough was used. The soil resistance to penetration was less on the sowing line than on between rows, with $20 \mathrm{~cm}$ deep.
\end{abstract}

KEYWORDS: furrow opener mechanism, soil firming mechanism, soil compaction.

\section{RESISTÊNCIA DE UM LATOSSOLO VERMELHO DISTROFÉRRICO À PENETRAÇÃO EM SISTEMA PLANTIO DIRETO APÓS SEMEADURA}

RESUMO: Práticas de manejo e semeadura mal conduzidas podem comprometer o meio ambiente e a rentabilidade da atividade agrícola. O objetivo deste trabalho foi estudar a ação de mecanismos sulcadores e a pressão da roda compactadora de uma semeadora-adubadora em plantio direto, na resistência de um Latossolo Vermelho distroférrico à penetração (RP), durante a semeadura da soja, sob três teores de água do solo. O experimento foi desenvolvido em esquema de blocos casualizados, arranjado em esquema de parcelas subsubdivididas, sendo as parcelas constituídas de três teores de água do solo $(23,8 ; 25,5$ e $27,5 \%$ b.s.), as subparcelas de dois mecanismos sulcadores (discos duplos e haste sulcadora) e as subsubparcelas de três pressões da roda compactadora (12,2; 18,5 e $24,1 \mathrm{kPa}$ ), com três repetições. O teor de água do solo promoveu diferença na RP com a profundidade, no leito de semeadura, independentemente do sulcador e da pressão da roda compactadora. O uso de haste sulcadora proporcionou menor RP comparada com o sulcador disco duplo, no leito de semeadura, independentemente do teor de água e da pressão da roda compactadora. A pressão aplicada pela roda compactadora de $18,5 \mathrm{kPa}$ proporcionou as menores resistências do solo à penetração, quando a haste sulcadora foi usado. A RP foi menor na linha de semeadura do que na entrefileiras, até $20 \mathrm{~cm}$ de profundidade.

PALAVRAS-CHAVE: mecanismo sulcador, roda compactadora, compactação do solo.

\footnotetext{
${ }^{1}$ Mestrando em Agronomia, Faculdade de Ciências Agrárias, UFGD, Dourados - MS, videvito@gmail.com.

${ }^{2}$ Eng $^{\circ}$ Agrícola, Prof. Adjunto, FCA/UFGD, Dourados - MS, csouza@ufgd.edu.br. Bolsista PQ/CNPq.

${ }^{3}$ Eng $^{\circ}$ Agrônomo, Prof. Associado, FCA/UFGD, Dourados - MS, Bolsista PQ/CNPq.

${ }^{4}$ Eng $^{\mathrm{O}}$ Agrícola, Profa. Adjunta, FCA/UFGD, Dourados - MS, zulys@ufgd.edu.br.

Recebido pelo Conselho Editorial em: 30-5-2011

Aprovado pelo Conselho Editorial em: 22-8-2011
} 


\section{INTRODUCTION}

The importance of environmental control in agricultural practices has received special attention in recent years. When poorly managed, they may compromise the environment and profitability. Among the developed conservation practices, no-till system (NTS) stands out, which through the past decades innovated Brazilian agriculture, because it is an effective technique in reducing the problems related to soil and water loss associated with erosion, when compared to conventional systems that revolve the soil during tillage operations.

However, studies such as FABRIZZI et al. (2005) and COLLARES et al. (2006) showed results in which the use of the NTS promoted soil compaction increase, caused mainly by systematic traffic of agricultural machinery (RICHART et al., 2005). Under no-till system, movement is restricted to the planting line, but the systematic occurrence of traffic causes compaction in the superficial layer of soil. In this sense, even in no-tillage system, the furrow opener mechanisms (FAGANELLO et al., 2008) and soil firming mechanism of seeders (SILVA et al., 2005) may cause different behaviors on the soil compaction.

REIS et al. (2006) report that the use of different opening mechanisms of the furrow, as double discs and furrow plough may promote differences in soil-seed. Similarly, SILVA et al. (2005), studying the effect of three different soil firming mechanism with vertical pressures in the sowing of maize, found that the level of load applied to the soil firming mechanism and the mechanism type may cause changes in physical attributes of the soil, causing soil compaction.

Studies of soil resistance to penetration have been used to evaluate the state of soil compaction (SUZUKI et al. 2007; MARCHÃO et al. 2007; LIMA et al., 2010), and it is important to consider that this attribute undergoes variations with water content and machine traffic intensity on the soil, especially when the humidity values are above the field capacity. SERAFIM et al. (2008), working with the control of the physical quality of a soil under different land use systems, found that the drying of the soil associated with the increase of density causes a marked increase in soil mechanical resistance. SILVA et al. (2005) concluded that the water content of the soil has great influence on deformation and soil compaction, which increases proportionally with the vertical loads on the soil firming mechanism, and that the higher the water content of soil, the more susceptible it is to compression and deformation.

Thus, this work aimed to study the resistance of an Oxisol to penetration during soybean sowing, using two mechanisms of furrow opener and three levels of pressure applied on the sowing line by the soil firming mechanism of a seeder-fertilizer in three levels of soil water.

\section{MATERIAL AND METHODS}

The study was conducted at the Agricultural Sciences College of the Federal University of Grande Dourados and at the field production of seed of the company Sementes Guerra, located in Dourados, State of Minas Gerais, Brazil. The regional climate ranked by the Köeppen international system is the Cwa type, humid climate in the summer and dry in the winter, with average annual rainfall of $1,500 \mathrm{~mm}$ and average annual temperature of $22{ }^{\circ} \mathrm{C}$. The studies were conducted in a soil classified as Oxisol, clayey texture (clay $=653 \mathrm{~g} \mathrm{~kg}^{-1}$; silt $=174 \mathrm{~g} \mathrm{~kg}^{-1}$ and sand $=173 \mathrm{~g} \mathrm{~kg}^{-1}$ soil), representative class of most soils in the south-central part of the State of Mato Grosso do Sul, and with an average slope of $2 \%$. The density of the soil before sowing was $1.28 \pm 0.11 \mathrm{Mg} \mathrm{m}^{-3}$.

The experimental area was cultivated under no-tillage system for 10 years, in which was found oat crop residues, used as a preceding crop. The area was desiccated with Glyphosate (i.a.) herbicide, of a dosage of $5.0 \mathrm{~L} \mathrm{ha}^{-1}$, diluted in water, corresponding to an application volume of $300 \mathrm{~L} \mathrm{ha}^{-1}$. The tests were conducted using a Seed-Max seeder-fertilizer, PC 2123 model, with three sowing rows, spaced $0.45 \mathrm{~m}$ between rows and a total mass of $640 \mathrm{~kg}$. The machine, mounted on the system of three-point hitch, presents mechanisms for simple operation and small size, and it is recommended to meet the needs of small and medium-sized farms. The model consists basically of flat straw cut disk, ground breaker mechanism, supplying fertilizers set, seeds feeder of horizontal 
honeycomb discs type, with adjustment made by an exchange of gears and the actuation by the sprocket and the soil firming mechanism of flat metal type V-shaped.

For the experiment, the seeder-fertilizer was pulled by a tractor, Massey Ferguson $2654 \times 2$ model, rated at $48 \mathrm{~kW}$ at 2,000 rpm motor, total mass of 3,300 kg. The speed was $1.47 \mathrm{~m} \mathrm{~s}^{-1}$, being within the stated range for sowing operation (OLIVEIRA et al., 2000). The tractor had front axles equipped with tires (F1) in size from 7.5 to 16 and rear with diagonal tires (R1) from 12.4 to 38 in size.

The experiment was conducted in a total area of $9,720 \mathrm{~m}^{2}$, in a randomized block design (RBD) in split-split plots using three levels of soil water as portions $(23.8 ; 25.5$ and $27.5 \%$ ), two types of furrow opener mechanisms as sub-plots (furrow plough and double disc), and three levels of load applied to soil firming mechanism as a split-split plot $(12.2 ; 18.5$ and $24.1 \mathrm{kPa})$, with three replicates. Each plot had dimensions of $50.0 \mathrm{~m} \mathrm{x} 2.0 \mathrm{~m}$, covering an area of $100 \mathrm{~m}^{2}$, of which $20.0 \mathrm{~m}$ of border is reserved to perform maneuvers with agricultural machinery.

Before the sowing, samples were collected to determine the water content of soil. The soil water contents were determined monitoring periodically their values after a rainfall, for adequacy of the plots at all three levels. We tried to work with water levels near and below the soil friable condition, as is recommended for operation with agricultural implements. Three levels of water content were determined by gravimetric method (standard oven method), according to the relation between water mass and the mass of dry soil at $105^{\circ} \mathrm{C}$ (EMBRAPA, 1997). Soil samples were collected in layers of $10 \mathrm{~cm}$ to $40 \mathrm{~cm}$ depth (Table 1).

TABLE 1. Soil water content as a function of the depth.

\begin{tabular}{cccc}
\hline Depth $(\mathrm{cm})$ & \multicolumn{3}{c}{ Water content $(\%)$} \\
\hline $0-10$ & 21.2 & 23.9 & 26.0 \\
$10-20$ & 22.1 & 24.4 & 26.3 \\
$20-30$ & 24.6 & 24.9 & 27.6 \\
$30-40$ & 27.5 & 28.9 & 30.1 \\
\hline Average & 23.8 & 25.5 & 27.5 \\
\hline Standard Deviation & 3.9 & 3.8 & 2.8 \\
\hline
\end{tabular}

The furrow opener mechanisms used were set to work at an average depth of $74.5 \pm 10.8 \mathrm{~mm}$. The diameter of the double-disc furrow opener was of $0.35 \mathrm{~m}$ and the furrow plough was $0.38 \mathrm{~m}$ high (from tip to the point of attachment to the chassis), $76.7 \mathrm{~mm}$ wide and $13.7 \mathrm{~mm}$ thick. The level of load applied to soil firming mechanism was defined by the relation between the applied force on the soil and the contact area of the wheel. The force applied on the soil was determined by means of a load cell, Alfa, Z250 model, with a capacity of $2.45 \mathrm{kN}$, attached to the soil firming mechanism of the seeder, through a fixed support (Figure 1).

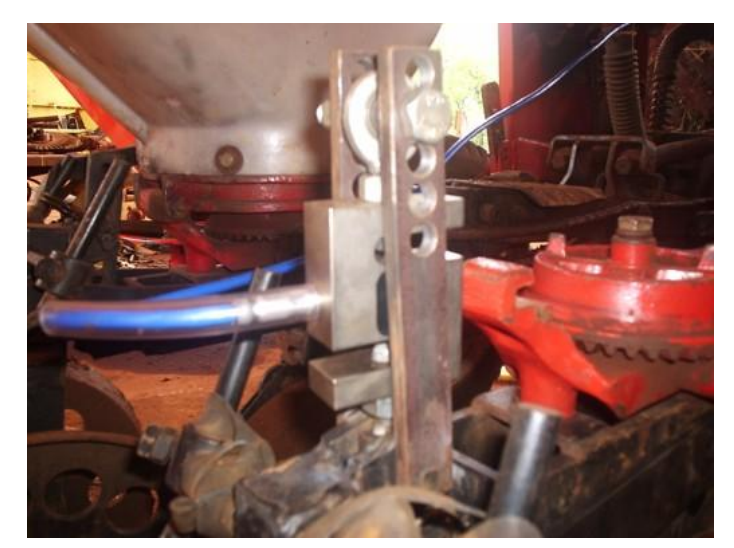

FIGURE 1. Location of the load cell in the seeder-fertilizer. 
The determination of soil resistance to penetration was performed immediately after soybean sowing, in the sowing line and between rows in all treatments, in the depth of 0 to $40 \mathrm{~cm}$, using a penetrometer, SoilControl brand, SC-60 model (according to methodology of ASABE, 2006a,b).

The data curves of soil resistance to penetration of the abacus obtained from the penetrometer were scanned and their values were processed using the computer program InterCone (ROS et al., 2007), developed using numerical methods (CHAPRA \& CANALE, 1998) to obtain data of soil resistance to penetration with depth increases. The analyzed data of soil resistance to penetration were obtained in increments of 5 to $5 \mathrm{~cm}$ deep.

The data were subjected to analysis of variance, as the levels of water, soil furrow openers, the level of load applied to soil firming mechanism, and soil depths, using the computer program SAEG, version 9.1 (RIBEIRO JÚNIOR, 2001). The averages were compared by Duncan test at $5 \%$ probability.

Comparing the curves of resistance to penetration depth, it was used the combination of the $\mathrm{F}$ test modified by Graybill (Equation 1), the t test applied to the mean error (Equation 2) and the explained variance $\left(\mathrm{r}^{2}\right)$, according to LEITE \& OLIVEIRA (2002). It was used 5\% probability in the comparisons between the curves of soil resistance to penetration.

$$
\begin{aligned}
& \mathrm{F}\left(\mathrm{H}_{0}\right)=\frac{(\beta-0)^{\prime}\left(\mathrm{Y}_{1}^{\prime} \mathrm{Y}_{1}\right)(\beta-\theta)}{2 \mathrm{MSR}} \sim \mathrm{F}_{\alpha}(2, \mathrm{n}-2) \\
& \mathrm{t}_{\overline{\mathrm{e}}}=\frac{\overline{\mathrm{e}}-0}{\mathrm{~S}_{\overline{\mathrm{e}}}} \sim \mathrm{t}_{\alpha}(\mathrm{n}-1)
\end{aligned}
$$

In which:

$$
\mathrm{S}_{\overline{\mathrm{e}}}=\frac{\mathrm{S}_{\mathrm{e}}}{\sqrt{\mathrm{n}}}
$$

$\mathrm{Y}_{1}$ - vector of standard values ( $\mathrm{x}$-axis);

$\beta$ - coefficient vectors $\left(\beta_{0}\right.$ and $\left.\beta_{1}\right)$;

MSR - mean square of the regression;

$\overline{\mathrm{e}}$ - relative mean error;

$S_{\bar{e}}$ - standard deviation of mean error;

$\mathrm{S}_{\mathrm{e}}$ - standard deviation;

$\mathrm{n}$ - number of observations;

$\alpha$ - significance of the F test;

$\mathrm{t}_{\overline{\mathrm{e}}}$ - value of the $\mathrm{t}$ test of mean error, and

$\mathrm{H}_{0}: \beta^{\prime}=\left[\begin{array}{ll}0 & 1\end{array}\right]$.

The relative mean error between the data curves of soil resistance to penetration was determined using Equation 4, considering that the error (Equation 5) is a variable that follows a normal distribution and occurs at random, one may test the hypothesis $\left(\mathrm{H}_{0}: \overline{\mathrm{e}}=0\right)$ that the relative mean error is zero:

$$
\begin{aligned}
& \overline{\mathrm{e}}=\frac{\sum_{\mathrm{i}}^{\mathrm{n}} \frac{\mathrm{Y}_{\mathrm{ji}}-\mathrm{Y}_{1 \mathrm{i}}}{\mathrm{Y}_{1 \mathrm{i}}}}{\mathrm{n}} \\
& \mathrm{e}=\frac{\mathrm{Y}_{\mathrm{j}}-\mathrm{Y}_{1}}{\mathrm{Y}_{1}}
\end{aligned}
$$

In which, $\mathrm{Y}_{\mathrm{j}}$ - vector of alternative values (y-axis); e - relative error; $\mathrm{i}=1,2, \ldots, \mathrm{n}$. 


\section{RESULTS AND DISCUSSION}

The lowest values of soil resistance to penetration in the three water contents studied were found in the 0 to $5 \mathrm{~cm}$ layer (Table 2), with resistance to penetration values increasing with decrease of water content. The lower values of resistance to penetration in the surface layer may be associated with the effects of higher concentrations of organic matter, which is consistent with reports of MOLIN et al. (2006), who also found lower resistance to penetration values in places with higher concentrations of organic matter, and this increase in organic matter content given by the increment of the straw cover in no-tillage system. Allied to this effect, the action of the furrow mechanism may be considered, which according to KOAKOSKY et al. (2007) provides a lower resistance to penetration, and greater effectiveness of the root system of plants to improve the porosity at this depth. The roots are flexible, their tips have small diameter and may present motions which facilitate their development (VEPRASKAS, 1994). Besides being lubricated, they can change direction, to overcome obstacles, such as aggregates or structures more densely populated, via channels and cracks. So, in no-tillage systems it appears a large quantity of biopores (TORRES \& SARAIVA, 1999), and these can improve soil porosity.

It was also emphasize that this range of soil is of great importance in relation to seed deposition, germination and establishment of the root system.

TABLE 2. Soil resistance to penetration $(\mathrm{MPa})$ in the sowing line as a function of the soil water content and of the depth.

\begin{tabular}{cccl}
\hline \multirow{2}{*}{ Depth $(\mathrm{cm})$} & \multicolumn{3}{c}{ Soil water content $(\%)$} \\
\cline { 2 - 4 } & 23.8 & 25.5 & 27.5 \\
\hline $0-5$ & $1.86 \mathrm{aD}$ & $0.57 \mathrm{bE}$ & $0.10 \mathrm{cE}$ \\
$5-10$ & $3.39 \mathrm{aAB}$ & $1.61 \mathrm{bB}$ & $0.47 \mathrm{cD}$ \\
$10-15$ & $3.54 \mathrm{aA}$ & $2.00 \mathrm{bA}$ & $1.58 \mathrm{cBC}$ \\
$15-20$ & $3.17 \mathrm{aB}$ & $1.75 \mathrm{cAB}$ & $2.39 \mathrm{bA}$ \\
$20-25$ & $2.69 \mathrm{aC}$ & $1.56 \mathrm{cBC}$ & $2.15 \mathrm{bAB}$ \\
$25-30$ & $2.44 \mathrm{aC}$ & $1.33 \mathrm{cCD}$ & $1.78 \mathrm{bBC}$ \\
$30-35$ & $2.49 \mathrm{aC}$ & $1.23 \mathrm{bD}$ & $1.48 \mathrm{bBC}$ \\
$35-40$ & $2.53 \mathrm{aC}$ & $1.27 \mathrm{bCD}$ & $1.35 \mathrm{bC}$ \\
\hline
\end{tabular}

Means followed by the same letters, in lower case in lines and capital letter in columns, do not differ from each other, at $5 \%$ probability, by the Duncan test.

In the water content of $23.8 \%$, there were higher values of soil resistance to penetration in all layers of the studied profile, when compared with higher concentrations of water, observing values greater than $3 \mathrm{MPa}$ in the layer of 5-20 cm. SENRA et al. (2007), working with soil resistance to penetration with different agricultural systems, found in no-till greater resistance in the range of 0 to $20 \mathrm{~cm}$ deep. CARVALHO et al. (2006), studying the productivity of bean related to soil resistance to penetration in a Oxisol, found mean values of penetration resistance between 1.3 and $2.9 \mathrm{MPa}$ in the depth of 0 to $30 \mathrm{~cm}$.

For the water content of $27.5 \%$, the highest resistance to penetration was found in the range of 15 to $25 \mathrm{~cm}$ depth (Table 2), where it is believed that there may be some difficulty or impediment to penetration into the root system in these layers. It can be argued that, for the study area is under no tillage for several years, where traffic systematic machinery, associated with inadequate water content of soil, may be contributing to compaction and increased resistance to penetration.

OLIVEIRA et al. (2003), studying tension and compressibility of water in a Clayey Oxisol, concluded that the pressures on land can decrease the porosity, hindering the development of plants. SILVA et al. (2006) found that the water content of the soil has great influence on the deformation and compression of it. 
Analyzing the soil depth from 5 to $25 \mathrm{~cm}$, in all water contents studied (Table 2), it was observed the highest values of soil resistance to penetration, and as they deepened in the soil profile, there was a decrease of their values until its stabilization. This fact may be related to the increase of water content in the layers that are distant from the soil surface (Table 1).

The decrease in soil resistance to penetration with increasing water content as it delves into the soil profile may be due to the water acting as a natural lubricant in the soil, facilitating the penetration of the penetrometer tip of the cone.

Figure 2 shows the comparison between the values of soil resistance to penetration obtained at different water contents in the soil. It is observed that the values of soil resistance to penetration were higher for the water content of $23.8 \%$, ensuring that the higher the water content, the less the resistance to penetration.

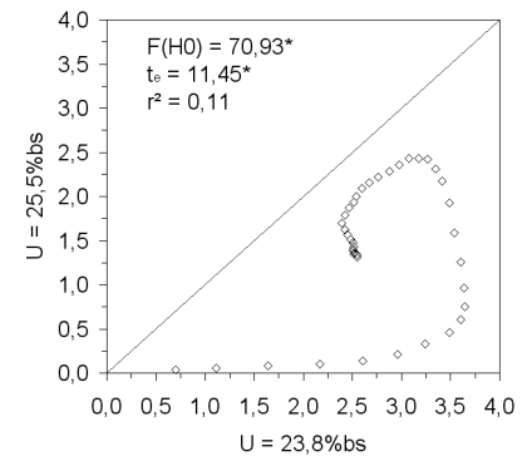

A

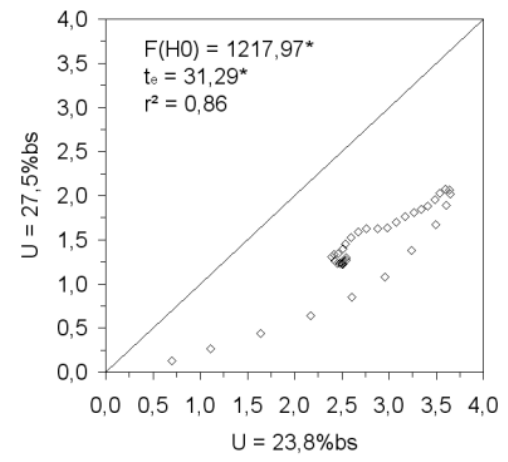

b

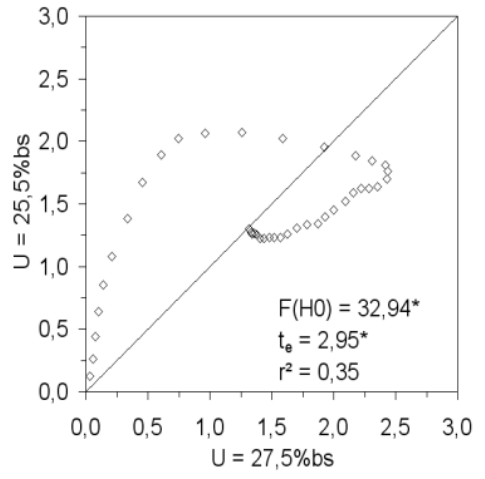

$\mathrm{c}$

* Significant at $5 \%$ probability, by the $\mathrm{F}$ and t tests.

FIGURE 2. Comparison among the curves of soil resistances to penetration (MPa) for different soil water content.

The soil resistance to penetration was higher in water content of $23.8 \%$ when compared to the water content of $25.5 \%$, verified by the significance of the $F$ test $\left(\beta_{0} \neq 0\right.$ and $\left.\beta_{1} \neq 1\right)$ and the $t$ test of the relative mean error $(\overline{\mathrm{e}} \neq 0)$, and which do not show similar behavior $\left(\mathrm{r}^{2}=0.11\right)$ between the curves (Figure 2a).

In Figure $2 b$, it can be observed higher values of resistance to penetration in soil of water content of $23.8 \%$ when compared to the water content of $27.5 \%$, verified by the significance of $\mathrm{F}$ test and $\mathrm{t}$ test of the relative mean error, however, despite having different values, they have similar behavior $\left(r^{2}=0.86\right)$.

The water content of $25.5 \%$ when compared to the water content of $27.5 \%$, showed the highest resistance to penetration in the soil (Figure 2c) in the depth of 0 to $15 \mathrm{~cm}$ (Table 2), where values were statistically significant by the test of relative mean error and the $\mathrm{F}$ test. At depths greater than $15 \mathrm{~cm}$, the values were reversed, and it was found the highest values of soil resistance to penetration to the water content of $27.5 \%$. Although it has been observed difference between the water contents of 25.5 and $27.5 \%$ in depths greater than $15 \mathrm{~cm}$, it would not be expected such behavior, indicating that there may be influenced by another factor not studied on the resistance to penetration.

Despite the highest values of soil resistance to penetration to the water content of $27.7 \%$ when compared to $25.5 \%$ at a depth greater than $15 \mathrm{~cm}$ (Figure 2c), they are considered below of the critical according to SERAFIM et al. (2008), which use to be of $2.0 \mathrm{MPa}$ for the mechanical impediment to root development.

The mean soil resistance to penetration depending on the type of furrow mechanism of the soil and the level of load applied to soil firming mechanism are shown in Table 3. 
TABLE 3. Soil resistance to penetration (MPa) in the sowing line, for the type of furrow opener mechanisms and the levels of load applied to soil firming mechanism.

\begin{tabular}{cccc}
\hline \multirow{2}{*}{ Furrow opener } & \multicolumn{3}{c}{ Level of load applied to soil firming mechanism $(\mathrm{kPa})$} \\
\cline { 2 - 4 } & 12.2 & 18.5 & 24.1 \\
\hline Double disc & $2.07 \mathrm{aA}$ & $2.10 \mathrm{aA}$ & $1.98 \mathrm{aA}$ \\
Furrow plough & $1.75 \mathrm{aB}$ & $1.53 \mathrm{bB}$ & $1.76 \mathrm{aB}$ \\
\hline
\end{tabular}

Means followed by the same letters, in lower case in lines and capital letter in columns, do not differ from each other, at $5 \%$ probability, by the Duncan test.

It appears that the double disc furrow opener did not influence the resistance to penetration with increasing the level of load applied to soil firming mechanism. However, the use of the furrow plough indicated that the resistance to penetration was lower when the level of load applied to soil firming mechanism was $18.5 \mathrm{kPa}$. There were significant differences between furrow openers mechanism, being found greater resistance to penetration mechanism in double disc (2.05 MPa) compared to the furrow plough $(1.68 \mathrm{MPa})$. It is believed that this fact is due to the double disc furrow plough to cut the surface layer of soil, reducing its revolving.

The differences between the furrow opener mechanisms were statistically significant due to the furrow plough to promote greater effect with regard to penetration and possible breaking of compacted layers near the seed in soils with higher clay content.

Working with scarification of the soil in no-tillage system, CAMARA \& KLEIN (2005) found that the furrow plough showed greater incorporation of crop residues on the soil that the double disc, due to its mode of action to mobilize more the soil.

Table 4 presents the averages of soil resistance to penetration for the different furrow opener mechanisms according to the depths.

TABLE 4. Soil resistance to penetration (MPa) in the sowing line, for the levels of load applied to soil firming mechanism and soil depth.

\begin{tabular}{cll}
\hline \multirow{2}{*}{$\begin{array}{c}\text { Depth } \\
(\mathrm{cm})\end{array}$} & \multicolumn{2}{c}{ Furrow openers } \\
\cline { 2 - 3 } $0-5$ & Double disc & Plough \\
$5-10$ & $1.07 \mathrm{aE}$ & $0.62 \mathrm{bD}$ \\
$10-15$ & $2.13 \mathrm{aBCD}$ & $1.52 \mathrm{bC}$ \\
$15-20$ & $2.72 \mathrm{aA}$ & $2.03 \mathrm{bABC}$ \\
$20-25$ & $2.66 \mathrm{aA}$ & $2.21 \mathrm{bAB}$ \\
$25-30$ & $2.27 \mathrm{aBC}$ & $1.99 \mathrm{bABC}$ \\
$30-35$ & $1.93 \mathrm{aCD}$ & $1.77 \mathrm{aBC}$ \\
$35-40$ & $1.81 \mathrm{aD}$ & $1.65 \mathrm{aC}$ \\
& $1.78 \mathrm{aD}$ & $1.65 \mathrm{aCD}$ \\
\hline
\end{tabular}

Means followed by the same letters, in lower case in lines and capital letter in columns, do not differ from each other, at $5 \%$ probability, by the Duncan test.

From the data shown in Table 4, it appears that at all depths; the furrow plough mechanism had lower values of resistance to penetration when compared to the double disc. It may attribute more ability to achieve greater depths of penetration to the furrow plough, because it mobilizes a larger area, breaking possible layers that perhaps affect the resistance to penetration. On the other hand, the double disc is more difficult to enter in certain layers, which is not a benefit on sowing in comparison to the furrow plough in no-tillage system. It was also noted that from $25 \mathrm{~cm}$ depth there was no difference in soil resistance to penetration of the furrow opener mechanisms. This fact is because from $25 \mathrm{~cm}$ depth there is no influence of furrow opener mechanisms. 
Table 5 presents the average soil resistance to penetration between rows of soybeans. There were higher values of soil resistance to penetration in the range of 5 to $20 \mathrm{~cm}$ deep, while from this range it tended to equal values (Table 5).

TABLE 5. Soil resistance to penetration, between soybean rows, as a function of soil depth.

\begin{tabular}{cc}
\hline Depth $(\mathrm{cm})$ & Resistance to penetration $(\mathrm{MPa})$ \\
\hline $0-5$ & $1.51 \mathrm{~F}$ \\
$5-10$ & $2.29 \mathrm{AC}$ \\
$10-15$ & $2.62 \mathrm{~A}$ \\
$15-20$ & $2.46 \mathrm{AB}$ \\
$20-25$ & $2.04 \mathrm{CD}$ \\
$25-30$ & $1.84 \mathrm{DE}$ \\
$30-35$ & $1.72 \mathrm{EF}$ \\
$35-40$ & $1.66 \mathrm{EF}$ \\
\hline
\end{tabular}

Means followed by the same letters do not differ from each other, at 5\% probability, by the Duncan test.

The gradual increase in soil resistance to penetration in the range of 5 to $20 \mathrm{~cm}$ may be related to natural consolidation of soil and great influence of machinery traffic, since the area is in notillage system for several years, without the respective revolving, resulting in greater resistance to penetration in this range.

In Figure 3 is shown the behavior of soil resistance to penetration in the sowing line and between crop rows. In general, we can see that the two curves of soil resistance to penetration have no identity $\left(\beta_{0} \neq 0\right.$ e $\left.\beta_{1} \neq 1\right)$, however they have behavior with $70 \%\left(\mathrm{r}^{2}\right)$ of similarity and the average deviations between their values were considered null ( $\overline{\mathrm{e}}=0)$.

In the range up to $20 \mathrm{~cm}$ depth, there are the greatest resistances to penetration on the between crop rows when compared to the sowing line. This indicates that the furrow opener mechanisms promote change in the resistance to penetration up to $20 \mathrm{~cm}$ depth (Figure 3), which is important for proper early development of crop.

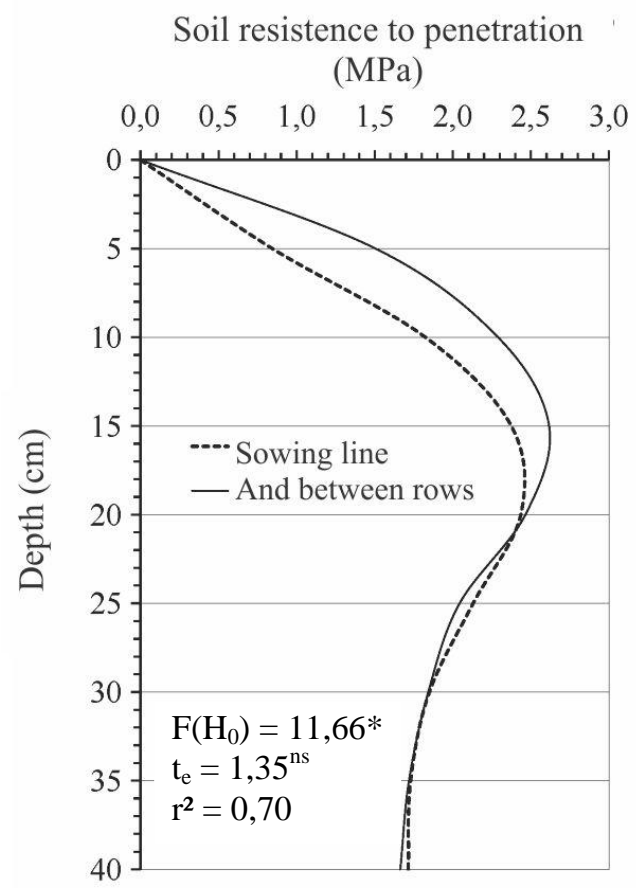

* $\mathrm{e}^{\mathrm{ns}}$ Significant and non-significant by the $\mathrm{F}$ e $\mathrm{t}$ tests, at $5 \%$ probability, respectively.

FIGURE 3. Soil resistance to penetration as a function of soil depth, in the sowing line and between rows of soybean. 
In the depth of 20 to $40 \mathrm{~cm}$, the values of soil resistance to penetration decreased as soil depth increased, both in the row and in the traffic of the tractor tire, resulting in similar values (Figure 3).

NAGAOKA et al. (2003), studying the penetration resistance of the soil after the traffic of the tractor with different types of tire, found higher values in the layer from 10 to $20 \mathrm{~cm}$ than in the one from 0 to $10 \mathrm{~cm}$, for the studied types of tires.

\section{CONCLUSIONS}

The water content of the soil provides different behavior of the resistance to penetration with depth, regardless of furrow opener and the level of load applied to soil firming mechanism, with higher values in the content of $23.8 \%$.

The use of furrow plough provided less resistance to penetration compared with the double disc furrow opener, in the seedbed, regardless of soil water content and level of load applied to soil firming mechanism.

The pressure applied by the soil firming mechanism of the seeder-fertilizer of $18.5 \mathrm{kPa}$ provided the lowest soil resistance to penetration, when the furrow plough was used, whereas there was no influence of level of load applied to double disc.

The soil resistance to penetration was lower in the sowing line than in between crop rows, up to $20 \mathrm{~cm}$ deep.

\section{ACKNOWLEDGEMENT}

To the Foundation to Support the Development of Education, Science and Technology of the State of Mato Grosso do Sul (FUNDECT) for financial support. To CNPq, for the scholarships granted. To the company Sementes Grandes ME, for research support.

\section{REFERENCES}

ASABE. American Society of Agricultural and Biological Engineers. Procedures for using and reporting data obtained with the soil cone penetrometer. ASABE Standard EP542. St. Joseph, 2006b. p.1053-1055.

ASABE. American Society of Agricultural and Biological Engineers. Soil cone penetrometer. ASABE Standard S313.2. St. Joseph, 2006a. p.903-904.

CÂMARA, R.K.; KLEIN, V.A. Escarificação em plantio direto como técnica de conservação do solo e da água. Revista Brasileira de Ciência do Solo, Viçosa-MG, v.29, p.789-796, 2005.

CARVALHO, G.J.; CARVALHO, M.P.; FREDDI, O.S.; MARTINS, M.V. Correlação da produtividade do feijão com a resistência à penetração do solo sob plantio direto. Revista Brasileira de Engenharia Agrícola e Ambiental, Campina Grande, v.10, p.765-771, 2006.

CHAPRA, S.C.; CANALE, R.P. Numerical methods for engineers. New York: WCB/McGrawHill, 1998. 924p.

COLLARES, G.L.; REINERT, D.J.; REICHERT, J.M.; KAISER, D.R. Qualidade física do solo na produtividade da cultura do feijoeiro num Argissolo. Pesquisa Agropecuária Brasileira, Brasília, v.41, n.11, p.1663-1674, 2006.

EMBRAPA. EMPRESA BRASILEIRA DE PESQUISA AGROPECUÁRIA. Centro Nacional de Pesquisa de Solos (CNPS). Manual de métodos de análise de solo. 2.ed. Rio de Janeiro:

EMBRAPA - CNPS, 1997. 212 p. (Documentos; 1). 
FABRIZZI, K.P.; GARCÍA, F.O.; COSTA, J.L.; PICONE, L.I. Soil water dynamics, physical properties and corn and wheat responses to minimum and no-tillage systems in the southern Pampas of Argentina. Soil \& Tillage Research, Amsterdam, v.81, p.57-69, 2005.

FAGANELLO, A.; DENARDIN, J.E.; KOCHHANN, R.A.; SATTLER, A. Efeito de mecanismos sulcadores de solo em semeadoras para plantio direto em pequenas unidades produtivas. Passo Fundo: Embrapa Trigo, 2008. 13 p.

KOAKOSKI, A.; SOUZA, C.M.A.; RAFULL; L.Z.L.; SOUZA, L.C.F.; REIS, E.F. Desempenho de semeadora-adubadora utilizando-se dois mecanismos rompedores e três pressões da roda compactadora. Pesquisa Agropecuária Brasileira, Brasilia, v.42, n.5, p.725-731, 2007.

LEITE, H.G.; OLIVEIRA, F.H.T. Statistical procedure to test identity between analytical methods. Commun. Soil Science Plant Anaysis, New York, v.33, p.1105-1118, 2002.

LIMA, C.L.R.; REINERT, D.J.; REICHERT, J.M.; SUZUKI, L.E.A.S. Produtividade de culturas e resistência à penetração de Argissolo Vermelho sob diferentes manejos. Pesquisa Agropecuária Brasileira, Brasília, v.45, n.1. p.89-98, 2010.

MARCHÃO. R.L.; BALBINO, L.C.; SILVA, E.M.; SANTOS JUNIOR, J.D.G.; SÁ, M.A.C.; VILELA, L.; BECQUER, T. Qualidade física de um Latossolo Vermelho sob sistemas de integração lavoura-pecuária no Cerrado. Pesquisa Agropecuária Brasileira, Brasília, v.42, n.6, p.873-882, 2007.

MOLIN, J.P.; MAGALHÃES, R.P.; FAULIN, G.C. Análise espacial da ocorrência do índice de cone em área sob semeadura direta. Engenharia Agrícola, Jaboticabal, v.26, n.2, p.442-452, 2006.

NAGAOKA, A.K.; LANÇAS, K.P.; CASTRO NETO, P.; LOPES, A.; GUERRA, S.P.S. Resistência do solo à penetração, após o tráfego com dois tipos de pneus utilizando-se um equipamento para ensaio dinâmico. Revista Brasileira de Engenharia Agrícola e Ambiental, Campina Grande, v.7, p.387-393, 2003.

OLIVEIRA, G.C; DIAS JUNIOR, M.S; CURI, N.; RESCK, D.V.S. Compressibilidade de um Latossolo Vermelho argiloso de acordo com a tensão de água no solo, uso e manejo. Revista Brasileira de Ciência do Solo, v.27, p.773-781, 2003.

OLIVEIRA, M.L.; VIEIRA, L.B.; MANTOVANI, E.C.; SOUZA, C.M.; DIAS, G.P. Desempenho de uma semeadora-adubadora para plantio direto, em dois solos com diferentes tipos de cobertura vegetal. Pesquisa Agropecuária Brasileira, Brasília, v.35, p.1455-1463, 2000.

REIS, E.F.; SHAEFER, C.E.G.R.; FERNANDES, H.C.; NAIME, J.M.; ARAÚJO, E.F. Densidade do solo no ambiente solo-semente e velocidade de emergência em sistema de semeadura de milho. Revista Brasileira de Ciência do Solo, Viçosa-MG, v.30, n.5, p.777-786, 2006.

RIBEIRO JUNIOR, J. I. Análises Estatísticas no SAEG. Viçosa: UFV, 2001. 301 p.

RICHART, A.; TAVARES FILHO, J.; BRITO, O.R; LLANILLO, R.F.; FERREIRA, R. Compactação do solo: causas e efeitos. Semina: Ciências Agrárias, Londrina, v.26, n.3, p.321-344, 2005.

ROS, V.V.; SOUZA, C.M.A.; VITORINO, A.C.T.; BOTTEGA, E.L.; RAFULL, L.Z.L. Resistência do solo à penetração em semeadura direta sob diferentes teores de água. In: CONGRESSO BRASILEIRO DE ENGENHARIA AGRÍCOLA, 36., 2007, Bonito. Anais... Jaboticabal: SBEA, 2007. 1 CD-ROM.

SENRA, A.F.; LOUZADA, R.O.; VITORINO, A.C.T.; SOUZA, C.M.A.; MOCHI-VICTOR, D. Resistência à penetração em latossolo vermelho sob diferentes sistemas de uso e manejo do solo. Revista Ciencias Técnicas Agropecuarias, La Habana, v.16, p.31-36, 2007. 
SERAFIM, M.E.; VITORINO, A.C.T.; PEIXOTO, P.P.P.; SOUZA, C.M.A.; CARVALHO, D.F. Intervalo hídrico ótimo em um latossolo vermelho distroférrico sob diferentes sistemas de produção. Engenharia Agrícola, Jaboticabal, v.28, n.4, p.654-665, 2008.

SILVA, R.P.; CORÁ, J.E.; LOPES, A.; FURLANI, C.E.A. Ação de rodas compactadoras de semeadoras submetidas a cargas verticais na deformação do solo. Ciência e Agrotecnologia, Lavras, v.29, n 4, p.839-847, 2005.

SILVA, R.P.; FURLANI, C.E.A.; LOPES, A.; NASCIMENTO, A.; CAMARA, F.T. Efeitos da roda compactadora de semeadoras sob cargas verticais na deformação do solo com dois teores de água. Engenharia Agrícola, Jaboticabal, v.26, p.511-519, 2006.

SUZUKI, L.E.A.S.; REICHERT, J.M.; REINERT, D.J.; LIMA, C.L.R. Grau de compactação, propriedades físicas e rendimento de culturas em Latossolo e Argissolo. Pesquisa Agropecuária Brasileira, Brasília, v.42, p.1159-1167, 2007.

TORRES, E.; SARAIVA, O.F. Camadas de impedimento do solo em sistemas agrícolas com a soja. Londrina: Embrapa Soja, 1999. 58 p. (Embrapa Soja. Circular Técnica, 23).

VEPRASKAS, M.J. Plant response mechanisms to soil compaction. In: WILKINSON, R.E. Plantenvironment interactions. New York: M. Dekker, 1994. p.263-287. 